\title{
WYBRANE ASPEKTY PRZESTĘPCZOŚCI SKIEROWANEJ PRZECIWKO INFORMACJOM NIEJAWNYM - ART. 265 I 266 K.K.
}

\begin{abstract}
Artykuł przedstawia zagadnienia warunkujące prawidłowe zabezpieczenie informacji niejawnych oraz konsekwencje wynikające $\mathrm{z}$ ujawnienia informacji niejawnych, przede wszystkim zawierających dane o szczególnym znaczeniu dla obronności państwa. Informacja znajduje się aktualnie w katalogu najważniejszych dóbr narodowych, szczególnie gdy zawiera treści, które mają bardzo duże znaczenie dla obronności państwa, jego bezpieczeństwa oraz prawidłowego funkcjonowania. W artykule omówiono w szczególności przestępstwa $\mathrm{z}$ art. 265 i 266 k.k.

Przestępstwo ujawnienia lub wykorzystanie informacji niejawnych, regulowane w art. 265 k.k. przewiduje odpowiedzialność karną osób, które ujawniają lub wbrew przepisom ustawowym, wykorzystują informacje niejawne o klauzuli „tajne” lub ,ściśle tajne”. Przepis ten reguluje nieumyślne ujawnienie takich informacji, z którymi zapoznano się w związku z pełnieniem funkcji publicznej lub otrzymanym upoważnieniem oraz typ kwalifikowany obejmujący sytuację, gdy informacje te zostały ujawnione osobie działającej w imieniu lub na rzecz podmiotu zagranicznego.

Natomiast na podstawie art. 266 k.k. odpowiedzialność karnej podlegają osoby, które wbrew przepisom ustawy lub przyjętemu na siebie zobowiązaniu, ujawniają lub wykorzystują informacje, z którymi zapoznały się w związku z pełnioną funkcją, wykonywaną pracą, działalnością publiczną, społeczną, gospodarczą lub naukową oraz funkcjonariusze publiczni, którzy ujawniają osobie nieuprawnionej informację niejawną o klauzuli ,zastrzeżone” lub „poufne” lub informacje, które uzyskali w związku z wykonywaniem czynności służbowych, a których ujawnienie może narazić na szkodę prawnie chroniony interes.
\end{abstract}

Słowa kluczowe: informacje niejawne, ochrona informacji, bezpieczeństwo, kodeks karny.

\section{ZAGADNIENIA WSTĘPNE}

Informacja znajduje się aktualnie w katalogu najważniejszych dóbr narodowych, szczególnie, gdy zawiera treści, które mają bardzo duże znaczenie dla obronności państwa, jego bezpieczeństwa oraz prawidłowego funkcjonowania.

Kwestia prawidłowego zabezpieczenia informacji jest problemem wieloaspektowym, dlatego też system ochrony informacji niejawnych obejmuje w szczególności: bezpie-

${ }^{1}$ Dr Dorota Kamuda, adiunkt, Katedra Prawa i Administracji, Wydział Zarządzania, Politechnika Rzeszowska im. Ignacego Łukasiewicza, Al. Powstańców Warszawy 12, 35-959 Rzeszów; e-mail: dkamuda@ prz.edu.pl.

Dorota Kamuda, PhD, Rzeszow University of Technology, Faculty of Management, Powstańców Warszawy 12, 35-959 Rzeszów; e-mail: dkamuda@prz.edu.pl. 
czeństwo osobowe, bezpieczeństwo fizyczne, bezpieczeństwo przemysłowe i bezpieczeństwo teleinformatyczne. Wskazane wyżej rodzaje bezpieczeństwa tworzą zbiór elementów wzajemnie ze sobą powiązanych, co powoduje, że tylko łączne ich zastosowanie zapewnia danym odpowiedni stopień ochrony.

Ważkość tej problematyki znajduje również swoje odzwierciedlenie w prawie karnym, które typizuje szereg przestępstw skierowanych przeciwko informacji. Do tej kategorii przestępstw należą w szczególności przestępstwa niedozwolonego ujawnienia informacji niejawnej, określone w art. 265 i 266 k.k., które są przedmiotem rozważań niniejszego opracowania $^{2}$.

Przestępstwo ujawnienia lub wykorzystanie informacji niejawnych, regulowane w art. 265 k.k., przewiduje odpowiedzialność karną osób, które ujawniają lub wbrew przepisom ustawowym, wykorzystują informacje niejawne o klauzuli „tajne” lub „ściśle tajne”. Przepis ten reguluje nieumyślne ujawnienie takich informacji, z którymi zapoznano się w związku z pełnieniem funkcji publicznej lub otrzymanym upoważnieniem oraz typ kwalifikowany obejmujący sytuację, gdy informacje te zostały ujawnione osobie działającej w imieniu lub na rzecz podmiotu zagranicznego.

Natomiast na podstawie art. 266 k.k. odpowiedzialność karnej podlegają osoby, które wbrew przepisom ustawy lub przyjętemu na siebie zobowiązaniu, ujawniają lub wykorzystują informacje, z którymi zapoznały się w związku z pełnioną funkcją, wykonywaną pracą, działalnością publiczną, społeczną, gospodarczą lub naukową oraz funkcjonariusze publiczni, którzy ujawniają osobie nieuprawnionej informację niejawną o klauzuli „zastrzeżone” lub „poufne” lub informacje, które uzyskali w związku z wykonywaniem czynności służbowych, a których ujawnienie może narazić na szkodę prawnie chroniony interes.

Obydwa wskazane wyże artykuły zostaną omówione w dalszej części artykułu.

W tekście pierwotnym Kodeksu karnego z 1997 r. art. 265 k.k. posługiwał się pojęciem „tajemnicy państwowej”, a art. 266 k.k. pojęciem „tajemnicy służbowej”, które to pojęcia w roku 2011 zostały zastąpione odpowiednio pojęciem informacji niejawnych o klauzuli „tajne” i ,ściśle tajne”, oraz pojęciem informacji niejawnych o klauzuli „zastrzeżone” i ,poufne”. Modyfikacje te zostały wprowadzone przez ustawę z dnia 5 sierpnia 2010 r. o ochronie informacji niejawnych ${ }^{3}$.

Uzasadnienie takiego rozwiązania wiązało się z krytyką istniejącego dwustopniowego systemu definiowania informacji niejawnych, a także zdaniem ustawodawcy nierespektowaniem w praktyce wykazów zawartych w załączniku do ustawy z dnia 22 stycznia 1999 r. o ochronie informacji niejawnych ${ }^{4}$, która oczywiście została uchylona ww. ustawą z roku 2010.

W tym miejscu konieczne jest zdefiniowanie chociażby pokrótce takich pojęć jak: informacje niejawne, klauzule nadane informacjom niejawnym.

Zgodnie z powołaną wyżej ustawą z dnia 5 sierpnia 2010 r. o ochronie informacji niejawnych za informacje niejawne uznaje się informacje, których nieuprawnione ujawnie-

\footnotetext{
${ }^{2}$ Zob. ustawa z dnia 6 czerwca 1997 r. Kodeks karny (tekst jedn. Dz.U. z 2017 r., poz. 2204 ze zm.), art. 265 i 266.

${ }^{3}$ Ustawa z dnia 5 sierpnia 2010 r. o ochronie informacji niejawnych (Dz.U. nr 182, poz. 1228), tekst pierwotny.

${ }^{4}$ Ustawa z dnia 22 stycznia 1999 r. o ochronie informacji niejawnych (tekst jedn. Dz.U. z 2005 r., nr 196, poz. 1631 ze zm.).
} 
nie spowodowałoby lub mogłoby spowodować szkody dla Rzeczypospolitej Polskiej albo byłoby z punktu widzenia jej interesów niekorzystne, także w trakcie ich opracowywania oraz niezależnie od formy i sposobu ich wyrażania ${ }^{5}$.

Informacja, której nadano określoną klauzulę, ma charakter niejawny, co pociąga za sobą skutki w zakresie odpowiedniego $\mathrm{z}$ nią postępowania $\mathrm{w}$ okresie ochronnym, w szczególności informacja taka może być udostępniona wyłącznie osobie uprawnionej do dostępu do danego rodzaju informacji niejawnych ${ }^{6}$.

Stopień zabezpieczenia informacji niejawnych jest uzależniony głównie od dokonanej ich klasyfikacji. Jej konsekwencją jest zaopatrzenie informacji niejawnych odpowiednią klauzulą poufności. Możliwe jest nadanie jednej z czterech klauzul: „ściśle tajne”, „tajne”, „,poufne”, ,zastrzeżone”. Jeżeli cały dokument został opatrzony określoną klauzulą tajności, to jednakowo chronione są wszystkie jego elementy ${ }^{7}$.

Klauzulą o najwyższym stopniu poufności jest klauzula ,ściśle tajne”, którą nadaje się informacjom niejawnym, jeżeli ich nieuprawnione ujawnienie mogłoby spowodować wyjątkowo poważną szkodę dla Rzeczypospolitej Polskiej przez to, że mogłoby: zagrozić niepodległości, suwerenności lub integralności terytorialnej Rzeczypospolitej Polskiej; zagrozić bezpieczeństwu wewnętrznemu lub porządkowi konstytucyjnemu Rzeczypospolitej Polskiej; zagrozić sojuszom lub pozycji międzynarodowej Rzeczypospolitej Polskiej; osłabić gotowość obronną Rzeczypospolitej Polskiej; doprowadzić do identyfikacji funkcjonariuszy, żołnierzy lub pracowników służb odpowiedzialnych za realizację zadań wywiadu lub kontrwywiadu, którzy wykonują czynności operacyjno-rozpoznawcze, jeżeli zagroziłoby to bezpieczeństwu wykonywanych czynności lub mogło doprowadzić do identyfikacji osób udzielających im pomocy w tym zakresie; zagrozić życiu lub zdrowiu funkcjonariuszy, żołnierzy lub pracowników, którzy wykonują czynności operacyjnorozpoznawcze, lub osób udzielających im pomocy w tym zakresie; zagrozić życiu lub zdrowiu świadków koronnych lub osób dla nich najbliższych albo tzw. świadków anonimowych lub osób dla nich najbliższych, czyli w sytuacji, gdy zachodzi uzasadniona obawa niebezpieczeństwa dla życia, zdrowia, wolności albo mienia w znacznych rozmiarach świadka lub osoby dla niego najbliższej ${ }^{8}$.

Kolejnym rodzajem klauzuli „tajne” zaopatruje się informacje niejawne, jeżeli ich nieuprawnione ujawnienie mogłoby spowodować poważną szkodę dla Rzeczypospolitej Polskiej przez to, że: uniemożliwiłoby realizację zadań związanych z ochroną suwerenności lub porządku konstytucyjnego Rzeczypospolitej Polskiej; pogorszyłoby stosunki Rzeczypospolitej Polskiej z innymi państwami lub organizacjami międzynarodowymi; zakłóciłoby przygotowania obronne państwa lub funkcjonowanie Sił Zbrojnych Rzeczypospolitej Polskiej; utrudniłoby wykonywanie czynności operacyjno-rozpoznawczych prowadzonych w celu zapewnienia bezpieczeństwa państwa lub ścigania sprawców zbrodni przez służby lub instytucje do tego uprawnione; w istotny sposób zakłóciłoby funkcjonowanie

${ }^{5}$ Ustawa z dnia 5 sierpnia 2010 r. o ochronie informacji niejawnych (tekst jedn. Dz.U. z 2016 r., poz. 1167 ze zm.), art. 1 ust. 1.

${ }^{6}$ Por. wyrok Wojewódzkiego Sądu Administracyjnego w Warszawie z dnia 8 grudnia 2011 r., II SA/Wa 1844/11, LEX nr 1153551.

${ }^{7}$ Zob. Wyrok Naczelnego Sądu Administracyjnego w Warszawie z dnia 26 marca 2013 r., I OSK 2863/12, LEX nr 1332343.

8 Por. A. Sakowicz, Komentarz do art. 265 k.k. [w:] Kodeks karny. Część szczególna, t. II: Komentarz do artykutów 222-316, red. M. Królikowski, R. Zawłocki, Warszawa 2017, s. 465 i n. 
organów ścigania i wymiaru sprawiedliwości; przyniosłoby stratę znacznych rozmiarów w interesach ekonomicznych Rzeczypospolitej Polskiej ${ }^{9}$.

Informacjom niejawnym nadaje się z kolei klauzulę ,poufne”, jeżeli ich nieuprawnione ujawnienie spowodowałoby szkodę dla Rzeczypospolitej Polskiej przez to, że: utrudniłoby prowadzenie bieżącej polityki zagranicznej Rzeczypospolitej Polskiej; utrudniłoby realizację przedsięwzięć obronnych lub negatywnie wpłynie na zdolność bojową Sił Zbrojnych Rzeczypospolitej Polskiej; zakłóciłoby porządek publiczny lub zagrozi bezpieczeństwu obywateli; utrudniłoby wykonywanie zadań służbom lub instytucjom odpowiedzialnym za ochronę bezpieczeństwa lub podstawowych interesów Rzeczypospolitej Polskiej; utrudniłoby wykonywanie zadań służbom lub instytucjom odpowiedzialnym za ochronę porządku publicznego, bezpieczeństwa obywateli lub ściganie sprawców przestępstw i przestępstw skarbowych oraz organom wymiaru sprawiedliwości; zagroziłoby stabilności systemu finansowego Rzeczypospolitej Polskiej; wpłynęłoby niekorzystnie na funkcjonowanie gospodarki narodowej ${ }^{10}$.

Najniższym rodzajem klauzuli nadawanym informacjom niejawnym jest klauzula „,zastrzeżone”, która przyznawana jest w sytuacji, gdy informacjom niejawnym nie nadano wyższej klauzuli tajności, a ich nieuprawnione ujawnienie może mieć szkodliwy wpływ na wykonywanie przez organy władzy publicznej lub inne jednostki organizacyjne zadań w zakresie obrony narodowej, polityki zagranicznej, bezpieczeństwa publicznego, przestrzegania praw i wolności obywateli, wymiaru sprawiedliwości albo interesów ekonomicznych Rzeczypospolitej Polskiej ${ }^{11}$.

\section{CHARAKTERYSTYKA PRZESTĘPSTWA Z ART. 265 K.K.}

\subsection{Przedmiot ochrony przestępstwa $z$ art. 265 k.k.}

Co do przedmiotu ochrony przestępstwa z art. 265 k.k., doktryna prezentuje różne stanowiska, niemniej jako wiodące należy uznać dwa spośród nich. Zgodnie z pierwszym bezpośrednim przedmiotem ochrony są podstawowe interesy państwa, natomiast według drugiego stanowiska za przedmiot ochrony należy uznać same informacje niejawne o klauzuli ,tajne” lub ,ściśle tajne”, bez nawiązywania w tym zakresie do bezpieczeństwa i interesu państwa.

Wydaje się, że najbardziej prawidłowym byłoby uznanie, że przedmiot ochrony przestępstwa ma podwójny charakter, bliższym jest poufność informacji, gdyż naruszenie tej sfery jej ochrony następuje na początku, a w konsekwencji możliwe jest powstanie stanu zagrożenia dla podstawowych interesów państwowych, które należy uznać za dalszy przedmiot ochrony ${ }^{12}$.

\footnotetext{
9 Por. R.G. Hałas, Komentarz do art. 265 k.k. [w:] Kodeks karny. Komentarz, red. A. Grześkowiak, K. Wiak, Warszawa 2017, s. 265 i n.

${ }^{10}$ Por. M. Leciak, Prawnokarne aspekty nowej ustawy o ochronie informacji niejawnych, Studia Iuridica Toruniensia, t. IX, Toruń 2011, s. 196.

${ }^{11}$ Por. S. Hoc, Komentarz do art. 266 k.k. [w:] Kodeks karny. Komentarz, red. R. Stefański, Warszawa 2017, s. 1607 i n.

12 Por. M. Leciak, Tajemnica państwowa i jej ochrona $w$ prawie karnym materialnym i procesie karnym, Torun 2009, s. 125.
} 


\subsection{Strona przedmiotowa przestępstwa $\mathrm{z}$ art. 265 k.k.}

$\mathrm{W}$ ramach strony przedmiotowej przestępstwa $\mathrm{z}$ art. $265 \S 1$ k.k. wymieniono dwa sposoby popełnienia tego przestępstwa. Pierwszym z nich jest ujawnienie informacji niejawnych o klauzuli tajne lub ściśle tajne, a drugim - wykorzystanie takich informacji wbrew przepisom ustawy ${ }^{13}$, które jest karalne tylko w typie podstawowym.

Przestępstwo opisane w art. $265 \S 2$ k.k. jest kwalifikowaną postacią czynu stypizowanego w art. $265 \S 1$ k.k. polegającego na ujawnieniu informacji. Różnica między ujawnieniem informacji niejawnej o klauzuli „tajne” lub „ściśle tajne”, ujętym w art. 265 $\S 1$ k.k., a czynem z art. $265 \S 2$ k.k. polega na tym, że w tym drugim przypadku sprawca ujawnia informację określoną $\mathrm{w} \S 1$ osobie działającej w imieniu lub na rzecz podmiotu zagranicznego, a zatem chodzi tu o szczególnego adresata ujawnionej informacji. Osobą taką może być zarówno polski obywatel, jak i cudzoziemiec ${ }^{14}$.

W art. $265 \S 1$ k.k. mowa jest o informacjach - w liczbie mnogiej, a w art. $265 \S 2$ i 3 k.k. użyto słowa ,informacja” w liczbie pojedynczej. Przyjąć należy, jako prawidłową wykładnię, że na podstawie przepisu art. $265 \S 1$ k.k. odpowiedzialności karnej podlega sprawca ujawnienia lub wykorzystania także pojedynczej informacji niejawnej o klauzuli „tajne” lub „ściśle tajne”15. Ponadto należy zwrócić uwagę, że zgodnie z aktualnym orzecznictwem sprawca odpowiada niezależnie od tego, czy określona klauzula nadana została przez uprawnionego w sposób prawidłowy, czy też z naruszeniem materialnych przesłanek przewidzianych $\mathrm{w}$ ustawie $\mathrm{z}$ dnia 5 sierpnia $2010 \mathrm{r}$. o ochronie informacji niejawnych ${ }^{16}$.

W przepisie art. $265 \S 3$ k.k. określono karalność nieumyślnego ujawnienia informacji niejawnej określonej w $\S 1$. Odpowiedzialność karna została zawężona wyłącznie do osób, które zapoznały się z taką informacją w związku z pełnieniem funkcji publicznej lub otrzymanym upoważnieniem. Jeżeli natomiast sprawca nieumyślnie ujawnił taką informację, którą uzyskał w inny sposób, to jego czyn nie stanowi przestępstwa.

Pod pojęciem ujawnienia rozumiemy wyjawienie tajemnicy, przekazanie wiadomości stanowiącej tajemnicę, zakomunikowaniem wiadomości, jej rozpowszechnianie, rozgłoszenie, udostępnienie, opublikowanie itp. Mieszczą się w nim różne sposoby działania sprawcy, takie jak wypowiedź ustna, udostępnienie pisma zawierającego tajemnicę, okazanie dokumentu lub przedmiotu, zamieszczenie w środkach przekazu. Ujawnienie informacji może nastąpić też przy użyciu komputera, np. przez nadanie jej pocztą elektroniczną, przy wykorzystaniu Internetu ${ }^{17}$.

W art. 5 ustawy o ochronie informacji niejawnych w definicji informacji niejawnych mowa jest o nieuprawnionym ujawnieniu. Ujawnienie wiadomości stanowiącej informa-

${ }^{13}$ B. Kunicka-Michalska, Przestępstwa przeciwko ochronie informacji [w:] Przestępstwa przeciwko państwu i dobrom zborowym. System Prawa Karnego, t. 8, red. L. Gardocki, Warszawa 2013, s. 878.

14 Zob. S. Hoc, Kilka uwag dotyczących przestępstwa z art. 265 k.k., ,Wojskowy Przegląd Prawniczy" nr 4/2003, s. 88.

${ }^{15}$ Por. M. Kalitowski, Komentarz do art. 265 k.k. [w:] Kodeks karny. Komentarz, red. M. Filar, Warszawa 2016, s. 1464 i n.; M. Leciak, Tajemnica państwowa i jej ochrona..., s. 130.

16 Zob. wyrok Sądu Apelacyjnego we Wrocławiu z dnia 16 czerwca 2016 r., sygn. akt II AKa 140/16, Lex nr 2073869.

17 Zob. B. Kunicka-Michalska, Przestępstwa przeciwko ochronie informacji $i$ wymiarowi sprawiedliwości. Rozdziat XXX i XXXIII. Komentarz, Warszawa 2000, s. 426. 
cje niejawne o klauzuli „tajne” lub „ściśle tajne” jest więc karalne tylko wtedy, gdy jest bezprawne.

Nieuprawnione ujawnienie to, po pierwsze: ujawnienie wobec osoby nieuprawnionej do poznania informacji, i po drugie: ujawnienie wbrew obowiązkowi dyskrecji ${ }^{18}$. Jeśli na danej osobie w konkretnych okolicznościach obowiązek dyskrecji nie ciąży, to ujawnienie informacji będzie uprawnione. Dlatego też, ujawnianie informacji, o których mowa w art. 265 k.k., będzie przestępstwem tylko wtedy, gdy nastąpi wobec osoby nieupoważnionej (nieuprawnionej) do poznania informacji niejawnych o klauzuli „tajne” lub ,ściśle tajne” i tylko wtedy, gdy sprawca nie będzie zwolniony z obowiązku zachowania tej tajemnicy. Zgodnie $\mathrm{z}$ orzecznictwem nie może być uznany za sprawcę przestępstwa, określonego w art. $265 \S 1$ k.k. ten, kto udostępnia informacje niejawne w granicach określonych jego prawami i obowiązkami ${ }^{19}$.

Alternatywnym sposobem popełnienia przestępstwa art. $265 \S 1$ k.k. jest wykorzystanie wbrew przepisom ustawy informacji niejawnych o klauzuli „tajne” lub „ściśle tajne”. Przyjmuje się, że przepis art. $265 \S 1$ k.k. jest przepisem podwójnie blankietowym oprócz tego, że pojęcie informacji niejawnych określone jest w innych ustawach, także wykorzystanie informacji niejawnych ma nastąpić wbrew przepisom innej (niż k.k.) ustawy. Doprecyzowanie znamion czynu następuje w odrębnych od k.k. ustawach.

Słowo „wykorzystuje” co do zasady oznacza osiągnięcie z czegoś pożytku, korzyści. Niemniej jest to słowo nieokreślone, a jego znaczenie nie jest klarowne. Do zakresu wykorzystywania informacji niejawnych możemy zaliczyć wszelkie działania podejmowane przez sprawcę, do których podjęcia podstawowym impulsem była znajomość informacji stanowiących informacje niejawne o klauzuli „tajne” lub ,ściśle tajne”, a które nakierowane są na uzyskanie określonej korzyści dla sprawcy lub innego podmiotu ${ }^{20}$. O wykorzystaniu informacji można mówić wówczas, gdy sprawca po zapoznaniu się z nią podjął określone decyzje gospodarcze, zmienił zakres prowadzonych badań naukowych czy opatentował określony wynalazek, wycofał wkłady dewizowe, dopuścił się szantażu wobec osób, których dane osobowe objęte są tajemnicą.

W kontekście wykorzystania informacji niejawnych w doktrynie występują dwa główne stanowiska. Pierwsze z nich przyjmuje, że wykorzystanie tego rodzaju informacji polega na posłużeniu się nimi w jakiejkolwiek działalności, z tym, że wykorzystanie to musi mieć charakter nielegalny. Drugie stanowisko uważa, że ta część typu czynu karalnego $\mathrm{z}$ art. $265 \S 1$ k.k., która penalizuje wykorzystywanie informacji stanowiących informacje niejawne o klauzuli „tajne” lub ,ściśle tajne”, ma zakres pusty. Jako uzasadnienie wskazuje się na brak na gruncie polskiego ustawodawstwa regulacji normatywnej o randze ustawy, która reglamentowałaby wykorzystywanie informacji stanowiących informacje niejawne o klauzuli „tajne” lub ,ściśle tajne”21.

Wydaje się, że stanowisko w kwestii alternatywnego sposobu popełnienia przestępstwa $\mathrm{z}$ art. $265 \S 1$ k.k. jest nietrafne. Trudno zgodzić się z jego stwierdzeniem, że w ustawie o ochronie informacji niejawnych brak jakichkolwiek regulacji odnoszących się

${ }^{18}$ Zob. S. Hoc, Kilka uwag..., s. 88 .

19 Zob. wyrok SN z dnia 8 marca 2007 r., sygn. akt I KZP 30/06, OSNKW nr 4/2007, poz. 32.

${ }^{20}$ Por. P. Kozłowska-Kalisz, Komentarz do art. 265 k.k. [w:] Kodeks karny. Komentarz, red. M. Mozgawa, Warszawa 2017, s. 611 i n.

${ }^{21}$ Zob. W. Wróbel, Prawnokarna ochrona tajemnicy państwowej, „Czasopismo Prawa Karnego i Nauk" Penalnych nr 1/2000, s. 160. 
do tej kwestii. Zakaz ujawnienia, a tym samym wykorzystania informacji stanowiących tajemnicę państwową można wyprowadzić $\mathrm{z}$ art. 3 ustawy o ochronie informacji niejawnych, który określa warunki, jakie muszą zostać spełnione, aby udostępnić innej osobie informację niejawną. Ustawą, o której mowa w art. 265 § 1 k.k. jest ustawa z dnia 5 sierpnia 2010 r. o ochronie informacji niejawnych, która jest aktem ogólnym regulującym ochronę informacji niejawnych, co oczywiście nie wyklucza możliwości uchwalenia innych ustaw dotyczących ochrony niektórych tylko informacji niejawnych.

Przestępstwo określone w art. 265 k.k. może być popełnione w postaci dokonania lub w postaci usiłowania. Usiłowaniem popełnienia przestępstwa $\mathrm{z}$ art. $265 \S 1$ k.k. jest np. nieumyślne narażenie na niebezpieczeństwo ujawnienia informacji niejawnych z zamiarem ujawnienia.

Możliwe są wszystkie postacie sprawstwa, o których mowa w art. 18 k.k. Możliwe jest również podżeganie i pomocnictwo. Przestępstwa ujawnienia informacji niejawnych mają charakter skutkowy, w przypadku znamienia ujawnienia skutkiem jest uczynienie informacji jawną, zapoznanie się z treścią informacji przez osobę nieuprawnioną, w odniesieniu zaś do znamienia wykorzystania skutkiem jest podjęcie czynności kwalifikowanych jako wykorzystanie informacji - osiągnięcie korzyści, pożytku z dysponowania informacją.

\subsection{Podmiot przestępstwa $z$ art. 265 k.k.}

Według przeważającego poglądu w doktrynie i orzecznictwie przestępstwo naruszenia informacji niejawnych, określone w art. $265 \S 1$ k.k. (typ podstawowy) i $§ 2$ k.k. (typ kwalifikowany) to przestępstwa ogólnosprawcze, gdyż podmiot przestępstwa określony został słowem „kto”22. Między innymi Sąd Najwyższy w uchwale z dnia 26 marca 2009 r. ${ }^{23}$ stwierdził, że „Przestępstwo określone w art. 265 § 1 k.k. ma charakter powszechny, a zatem może być popełnione przez każdą osobę odpowiadającą ogólnym cechom podmiotu przestępstwa, która ujawnia informacje stanowiące tajemnicę państwową [obecnie informacje niejawne o klauzuli »tajne« lub »ściśle tajne« - przyp. aut.] lub wbrew przepisom ustawy informacje takie wykorzystuje”. Pogląd ten zasługuje na aprobatę również w aktualnym stanie prawnym.

Niemniej niektórzy przedstawiciele doktryny uważają, że ma ono charakter indywidualny. Zgodnie z tym poglądem typ czynu wyrażony w art. $265 \S 1$ k.k. jest typem indywidualnym, gdyż w systemie prawnym znajduje się akt prawny mający charakter podstawowy dla materii związanej ochroną informacji niejawnych, w sposób dostateczny i precyzyjny regulujący tę dziedzinę, w szczególności zawężający krąg podmiotów zobowiązanych do zachowania ich tajności ${ }^{24}$. Istnieje również stanowisko, zgodnie z którym w art. $265 \S 1$ k.k. ustawodawca stypizował dwa czyny zabronione, jeden polegający na ujawnianiu i do niego odnosi się zaimek „kto”, oraz drugi opierający się na wykorzystywaniu, do którego odnosi się określenie „wbrew przepisom ustawy”. Według tego stanowiska o ile to pierwsze przestępstwo miałoby charakter powszechny z uwagi na zastosowany

${ }^{22}$ Por. J. Piórkowska-Flieger, Komentarz do art. 265 k.k. [w:] Kodeks karny. Komentarz, red. T. Bojarski, Warszawa 2016, s. 787 i n.

${ }^{23}$ I KZP 35/08, OSNKW 2009, nr 5, poz. 33.

${ }^{24}$ Por. W. Zontek, Sposoby wyznaczania zakresu treści normy sankcjonowanej. Uwagi na marginesie uchwaty SN z 26 marca 2009 r., sygn. akt I KZP 35/8, cz. 2, „Palestra” nr 1-2/2010, s. 50 i n. 
zaimek, o tyle to drugie posiada charakter indywidualny z uwagi na odwołanie się o ustawy, która dotyczy ściśle określonego kręgu podmiotów ${ }^{25}$.

\subsection{Strona podmiotowa przestępstwa $\mathrm{z}$ art. 265 k.k.}

Przestępstwo określone w art. $265 \S 1$ k.k. (typ podstawowy) ma charakter umyślny, sprawca tego przestępstwa musi być świadomy, iż informacje, które ujawnia lub wykorzystuje, noszą cechy informacji niejawnych o klauzuli „tajne” lub „ściśle tajne” ujęte w ustawie z dnia 5 sierpnia 2010 r. o ochronie informacji niejawnych. Popełnienie tego przestępstwa jest możliwe także $\mathrm{z}$ zamiarem ewentualnym, gdy sprawca, podejmując określone działania, ma świadomość, iż mogą one $\mathrm{z}$ wysokim prawdopodobieństwem prowadzić do zapoznania się z informacjami niejawnymi przez osobę do tego nieuprawnioną.

Umyślność ujawnienia informacji niejawnych jest wykluczona w przypadku, gdy sprawca błędnie sądzi, iż osoba, której przekazuje informację, zna już jej treśćc ${ }^{26}$. Koniecznym warunkiem umyślności jest bowiem świadomość sprawcy, iż to, co robi, ma charakter ujawnienia, a więc zapoznawania z informacją niejawną osoby, która nie zna tej informacji.

Przestępstwo określone w art. $265 \S 2$ k.k. (typ kwalifikowany) ma charakter umyślny, jest ono możliwe do popełnienia z zamiarem zarówno bezpośrednim, jak i ewentualnym.

Przestępstwo określone w art. $265 \S 3$ k.k. jako przestępstwo nieumyślne, może być popełnione, jeżeli sprawca, nie mając zamiaru jego dokonania, popełnia je jednak na skutek niezachowania ostrożności wymaganej w danych okolicznościach, mimo że możliwość popełnienia tego czynu przewidywał albo mógł przewidzieć (art. 9 § 2 k.k.).

\subsection{Karalność i tryb ścigania przestępstwa z art. 265 k.k.}

Za popełnienie przestępstwa określonego w art. $265 \S 1$ k.k. (typ podstawowy) przewidziana jest kara pozbawienia wolności od 3 miesięcy do lat 5. Ustawowy wymiar kary za ten czyn uprawnia sąd do orzeczenia grzywny lub kary ograniczenia wolności zamiast kary pozbawienia wolności. Typ kwalifikowany przestępstwa ujawnienia informacji niejawnych o klauzuli „tajne” lub” ściśle tajne” (art. 265 § 2 k.k.) zagrożony jest karą pozbawienia wolności od 6 miesięcy do lat 8 . Za przestępstwo przewidziane w art. 265 $\S 3$ k.k. ustanowiona jest kara grzywny, ograniczenia wolności albo pozbawienia wolności do roku.

W zakresie środków karnych sąd może orzec zakaz zajmowania określonego stanowiska albo wykonywania określonego zawodu (art. $41 \S 1$ k.k.).

Przestępstwa określone w art. 265 k.k. ścigane są z oskarżenia publicznego.

\section{CHARAKTERYSTYKA PRZESTĘSPTWA Z ART. 266 K.K.}

\subsection{Przedmiot ochrony}

Bezpośrednim przedmiotem ochrony jest prawo zachowania określonych informacji w tajemnicy, przy czym obowiązek dyskrecji ciąży na depozytariuszu informacji podyktowany być może potrzebą ochrony istotnego interesu prywatnego, stosunku zaufania

${ }^{25}$ Zob. E. Czarny-Drożdżejko, Odpowiedzialność karna za ujawnienie $i$ wykorzystanie informacji niejawnych (po nowelizacji), „Państwo i Prawo” nr 1/2013, s. 65 i n.

${ }^{26}$ Zob. W. Wróbel, Przestęstwa przeciwko ochronie informacji [w:] A. Zoll, Kodeks karny. Komentarz, Warszawa 2008, s. 1261. 
łączącego dysponenta informacji z jej depozytariuszem, jak również prawidłowego wykonywania określonych zawodów czy prowadzenia określonej działalności, w których szczególne znaczenie ma stosunek zaufania ${ }^{27}$.

\subsection{Strona przedmiotowa}

Do znamion przestępstwa z art. $266 \$ 1$ k.k. należy ujawnienie lub wykorzystanie informacji tylko wtedy, gdy następuje ono wbrew przepisom ustawy lub przyjętemu na siebie zobowiązaniu ${ }^{28}$. Odpowiedzialność z art. 266 § 1 k.k. wejdzie w grę wówczas, jeśli ustawa szczególna, zobowiązująca do dyskrecji przedstawiciela np. danego zawodu, nie będzie tworzyć na zasadzie lex specialis odrębnego przepisu przewidującego odpowiedzialność karną za naruszenie danego rodzaju tajemnicy ${ }^{29}$. Natomiast, gdy chodzi o przyjęte na siebie zobowiązanie, to mamy do czynienia z sytuacją, gdy sprawca zobowiązał się do zachowania dyskrecji co do powierzonej mu tajemnicy, chociażby nie zobowiązywał go do tego konkretny przepis prawa.

Obowiązek dochowania tajemnicy musi ciążyć na sprawcy przestępstwa z art. $266 \S 1$ k.k. nie tylko w chwili ujawnienia informacji, lecz także w chwili zapoznania się z nią ${ }^{30}$.

Warto zauważyć, iż osoby zobowiązane do zachowania w tajemnicy informacji niejawnych o klauzuli tajności „zastrzeżone” lub ,poufne” lub tajemnicy związanej z wykonywaniem zawodu lub funkcji mogą być zwolnione z zachowania tajemnicy w razie wezwania do złożenia zeznań w postępowaniu karnym.

Karalność ujawnienia oraz wykorzystania informacji obejmuje wyłącznie informacje, z którymi sprawca zapoznał się w związku z pełnioną funkcją, wykonywaną pracą, działalnością publiczną, społeczną, gospodarczą lub naukowąą ${ }^{31}$ Zapoznać się zatem z informacją musi sam sprawca przestępstwa, a wyliczenie ujęte w art. $266 \S 1$ k.k. obejmuje wszelkie formy społecznego funkcjonowania człowieka.

Nie stanowi przestępstwa z art. $266 \S 1$ k.k. ujawnienie lub wykorzystanie informacji zdobytej w inny sposób, np. usłyszanej na prywatnym przyjęciu czy też przekazanej przez prywatnego znajomego. Nie stanowi też przestępstwa $\mathrm{z}$ art. $266 \S 1$ k.k. wykorzystanie informacji uzyskanej nie przez sprawcę omawianego czynu, lecz przez inną osobę np. w związku z jej pracą. Nie dochodzi również do realizacji znamion czynu zabronionego $\mathrm{z}$ art. 266 k.k., gdy informację stanowiącą tajemnicę przekazuje się osobie, której treść tej informacji była wcześniej znana. Pojęcie ujawnienia zakłada bowiem, iż sprawca tego czynu zapoznaje dopiero inną osobę z informacjami, do których dotychczas nie miała dostępu ${ }^{32}$.

W art. $266 \S 2$ k.k. określono przestępstwo ujawnienia przez funkcjonariusza publicznego informacji niejawnej o klauzuli „zastrzeżone” lub „poufne” albo informacji

${ }^{27}$ Zob. W. Wróbel, Przestęsstwa przeciwko ochronie informacji [w:] A. Wąsek, Kodeks karny. Komentarz, t. II, Warszawa 2006, s. 1264.

${ }^{28}$ Por. E. Czarny-Drożdżejko, Odpowiedzialność karna za ujawnienie..., s. 65 i n.

${ }^{29}$ S. Hoc, Karnoprawna ochrona tajemnicy zawodowej, funkcyjnej i stużbowej, „Gdańskie Studia Prawnicze" nr 1/2008, s. 131 i n.

${ }^{30}$ Zob. K. Brocławik, Prawnokarne aspekty ochrony tajemnicy osób świadczacych pomoc prawna, „Czasopismo Prawa Karnego i Nauk Penalnych” nr 1/2000, s. 201; M. Szewczyk, Prawnokarna ochrona tajemnicy zawodowej lekarza, „Czasopismo Prawa Karnego i Nauk Penalnych” nr $1 / 2000$, s. 161.

31 A. Sakowicz, Komentarz do art. 266 k.k..., s. 465 i n.

${ }^{32}$ Zob. K. Brocławik, Prawnokarne aspekty ochrony tajemnicy..., s. 201. 
uzyskanej w związku z wykonywaniem czynności służbowych, której ujawnienie może narazić na szkodę prawnie chroniony interes.

Z brzmienia art. $266 \S 2$ k.k. wynika, że chodzi o ujawnienie informacji ,osobie nieuprawnionej", będzie to osoba, która nie została przez przepisy prawa dopuszczona do poznania danej tajemnicy. Ujawnienie informacji osobie uprawnionej, czyli upoważnionej do jej poznania, nie jest przestępstwem. Uprawnienie do ujawnienia informacji może wynikać z umocowania uzyskanego z mocy prawa lub wyraźnych przepisów albo z przewidzianego przepisami prawa zwolnienia z obowiązku zachowania tajemnicy.

Czyn ujęty w art. 266 k.k. może być popełniony w postaci dokonania, jak i w postaci usiłowania. Możliwe są wszystkie postacie sprawstwa, o których mowa w art. $18 \S 1$ k.k. Możliwe jest też podżeganie i pomocnictwo.

\subsection{Podmiot przestępstwa $\mathrm{z}$ art. 266 k.k.}

Przestępstwo z art. $266 \S 1$ k.k. jest przestępstwem tzw. indywidualnym co do czynu. Jego podmiotem będzie osoba, która zapoznała się $\mathrm{z}$ informacją $\mathrm{w}$ związku $\mathrm{z}$ pełnioną funkcją, wykonywaną pracę, działalnością publiczną, społeczną, gospodarczą lub naukową $^{33}$. Przyjąć należy, że podmiotem przestępstwa może być tylko osoba, na której ciąży obowiązek zachowania w tajemnicy informacji, albo zakaz jej wykorzystania ${ }^{34}$.

Natomiast osoby, które są funkcjonariuszami publicznymi w rozumieniu art. 115 $\S 13$ k.k. mogą odpowiadać z art. $266 \S 1$ k.k., jeśli ich czyn nie spełnia znamion przestępstwa $\mathrm{z}$ art. $266 \S 2$ k.k..

Przestępstwo ujawnienia informacji niejawnej o klauzuli „zastrzeżone” lub „poufne” ujęte w art. $266 \S 2$ k.k. jest przestępstwem indywidualnym, a jego podmiotem może być wyłącznie funkcjonariusz publiczny (art. $115 \S 13$ k.k.). Sprawcą przestępstwa z art. 266 $\S 2$ k.k. może być tylko osoba, która jest funkcjonariuszem publicznym w chwili dokonywania czynu, czyli w chwili ujawnienia informacji, a nie przedtem lub potem ${ }^{35}$.

\subsection{Strona podmiotowa przestępstwa $z$ art. 266 k.k.}

Przestępstwo z art. $266 \S 1$ k.k. może być popełnione tylko umyślnie z zamiarem bezpośrednim lub ewentualnym, przestępstwo ujawnienia informacji niejawnej o klauzuli zastrzeżone lub poufne (art. $266 \S 2$ k.k.) jest również przestępstwem umyślnym i może być popełnione z zamiarem bezpośrednim lub ewentualnym.

\subsection{Karalność i tryb ścigania przestępstwa z art. 266 k.k.}

Za popełnienie czynu określonego w art. $266 \S 1$ k.k. przewidziana jest kara grzywny, ograniczenia wolności albo pozbawienia wolności do lat 2. Możliwe jest odstąpienie od wymierzenia kary (art. 59 k.k.) lub warunkowe umorzenie postępowania karnego (art. 66 k.k.). Przestępstwo określone w art. $266 \S 2$ k.k. zagrożone jest karą pozbawienia wolności do lat 3 . Ustawowy wymiar kary za ten czyn pozwala również na zastosowanie insty-

\footnotetext{
${ }^{33}$ Por. M. Nawrocki, Kodeks karny. Komentarz [w:] Biegly w postępowaniu cywilnym i karnym. Komentarz praktyczny, orzecznictwo, wzory pism procesowych, red. K. Flaga-Gieruszyńska, Warszawa 2017, Legalis.

${ }^{34}$ Zob. K. Brocławik, M. Czajka, Prawnokarne aspekty ochrony tajemnicy zawodowej radcy prawnego, cz. I: Zagadnienia materialnoprawne, Radca prawny Nr 3/2001, s. 36.

35 Por. B. Gadecki, Kodeks karny. Czesść szczególna. Art. 252-316. Komentarz, Warszawa 2017, s. 67.
} 
tucji przewidzianych w art. 59 i 66 k.k. Możliwe jest także orzeczenie grzywny lub kary ograniczenia wolności zamiast kary pozbawienia wolności (art. 58 § 3 k.k.).

W zakresie środków karnych, w razie skazania za przestępstwa określone w art. 266 k.k., skąd może orzec zakaz zajmowania określonego stanowiska albo wykonywania określonego zawodu lub zakaz prowadzenia określonej działalności gospodarczej.

Przestępstwo określone w art. $266 \S 1$ k.k. ścigane jest na wniosek pokrzywdzonego (art. $266 \S 3$ ). Natomiast ściganie przestępstwa określonego w art. $266 \S 2$ k.k. następuje $\mathrm{z}$ oskarżenia publicznego.

\section{PODSUMOWANIE}

Informacja znajduje się aktualnie w katalogu najważniejszych dóbr narodowych, szczególnie, gdy zawiera treści, które mają bardzo duże znaczenie dla obronności państwa, jego bezpieczeństwa oraz prawidłowego funkcjonowania. $\mathrm{Z}$ kolei ochrona przed niepożądanym czy to świadomym czy też przypadkowym ujawnieniem, modyfikacją, zniszczeniem lub uniemożliwieniem przetwarzania informacji nazywana jest bezpieczeństwem informacyjnym ${ }^{36}$. Ten rodzaj bezpieczeństwa może dotyczyć podmiotu indywidualnego lub zbiorowego, który będzie zagrożony utratą zasobów informacyjnych lub możliwością uzyskania informacji złej jakości. Dlatego też bezpieczeństwo informacyjne oznaczać może również uzasadnione zaufanie podmiotu do jakości i dostępności pozyskiwanej a także wykorzystywanej informacji ${ }^{37}$. Do czynników, które mają wpływ na bezpieczeństwa informacyjne państwa można zaliczyć w szczególności: zagrożenia odnoszące się do praw obywatelskich, zagrożenia technologiczne, zagrożenia wynikające z niedostatecznych strukturalnych i organizacyjnych rozwiązań, tradycyjne zagrożenia informacyjne i zagrożenia losowe ${ }^{38}$.

Najważniejszym obecnie obowiązującym aktem prawnym definiującym pojęcie informacji niejawnych oraz dokonującym ich klasyfikacji jest ustawa $\mathrm{z}$ dnia 5 sierpnia 2010 r. o ochronie informacji niejawnych ${ }^{39}$. Ustawa ta reguluje ponadto m.in. zasady: organizowania ochrony informacji niejawnych; ich przetwarzania; organizacji kontroli stanu zabezpieczenia informacji niejawnych; ochrony informacji niejawnych w systemach teleinformatycznych; stosowania środków bezpieczeństwa fizycznego w odniesieniu do informacji niejawnych.

Przyczyną uchwalenia ustawy z dnia 5 sierpnia 2010 r. o ochronie informacji niejawnych, która zastąpiła poprzednio obowiązującą ustawę z dnia 22 stycznia 1999 r. o takiej samej nazwie, była konieczność dostosowania przepisów do ogromnego postępu technologicznego, który miał miejsce przede wszystkim w zakresie środków łączności i systemów teleinformatycznych. Szczególnie przestarzałe rozwiązania z zakresu bezpieczeństwa teleinformatycznego i fizycznego nie były dostosowane do możliwości współczesnej

\footnotetext{
${ }^{36}$ K. Liedel, Cyberbezpieczeństwo - wyzwanie przyszłości. Działania społeczności międzynarodowej [w:] K. Liedel, P. Piasecka, T.R. Aleksandrowicz, Bezpieczeństwo w XXI wieku. Asymetryczny świat, Warszawa 2011, s. 438.

${ }^{37}$ K. Liderman, Bezpieczeństwo informacyjne, Warszawa 2012, s. 22.

38 Por. P. Bączek, Zagrożenia informacyjne a bezpieczeństwo państwa polskiego, Toruń 2005, s. 72.

${ }^{39}$ Ustawa z dnia 5 sierpnia 2010 r. o ochronie informacji niejawnych (Dz.U. nr 182, poz. 1228).
} 
techniki. Ponadto wprowadzenie nowoczesnych regulacji zabezpieczających informacje niejawne spowodowane było zmianami prawa Unii Europejskiej oraz $\mathrm{NATO}^{40}$.

Wskazując relacje pomiędzy ochroną informacji niejawnych a bezpieczeństwem państwa należy zauważyć, że skuteczne działanie w zakresie ochrony ważnych zasobów informacyjnych wymaga utajnienia części informacji w sposób uniemożliwiający ewentualnemu przeciwnikowi przeciwdziałaniu przyjętemu zamierzeniu. Bardzo duże znaczenie ma prawidłowe określenie zakresu i rodzaju informacji podlegających ochronie ${ }^{41}$. Celem ograniczenia dostępu do pewnych kategorii informacji i objęcia ich specjalnym systemem bezpieczeństwa jest między innymi ochrona podstawowych interesów Rzeczypospolitej Polskiej. Przedstawiony w ustawie system postępowań sprawdzających i procedur ochrony ma uniemożliwić uzyskanie dostępu do chronionych informacji przez podmioty, które mogłyby je wykorzystać w sposób zagrażający podstawowym interesom państwa, a przede wszystkim niepodległości, nienaruszalności terytorium, interesom obronności oraz bezpieczeństwa państwa i obywateli. Dlatego też tryb utajniania informacji oraz procedury kontrolne procesu utajniania są szczególnie ważne ${ }^{42}$.

Niemniej należy zauważyć, że przesłanki uznania informacji za niejawną zostały zredagowane ogólnikowo przy wykorzystaniu pojęć w przeważającym stopniu nieostrych, co nie gwarantuje jednolitej praktyki ich stosowania i może wywołać niekorzystne skutki, tak w zakresie ochrony informacji niejawnych, jak i nieuprawnionego ograniczania dostępu do informacji publicznej ${ }^{43}$. W szczególności podmiot zobowiązany do udzielenia informacji publicznej może odmówić jej udzielenia z uwagi na ochronę informacji niejawnych. Stanowisko, które sprowadza się do odmowy udzielenia takiej informacji, przybiera procesową formę decyzji administracyjnej ${ }^{44}$.

W przypadku nieprawidłowego zakwalifikowania informacji do jednej z kategorii informacji niejawnych, istnieje zagrożenie, że zostanie naruszone prawo każdego polskiego obywatela, zagwarantowane w art. 61 ust. 1 Konstytucji Rzeczypospolitej Polskiej, do uzyskiwania informacji o działalności organów władzy publicznej oraz osób pełniących funkcje publiczne, które to uprawnienie obejmuje również uzyskiwanie informacji o działalności organów samorządu gospodarczego i zawodowego, a także innych osób oraz jednostek organizacyjnych w zakresie, w jakim wykonują one zadania władzy publicznej i gospodarują mieniem komunalnym lub majątkiem Skarbu Państwa.

Podsumowując należy zwrócić również na to, że w drodze przedstawionego ukształtowania znamion ustawowych art. 265 i 266 k.k., doprowadzono do sytuacji, w której byt ww. przestępstw uzależniony został w dużym stopniu od uznania urzędnika, który nadaje informacjom niejawnym odpowiednią klauzulę: „ściśle tajne, „tajne”, „poufne”, ,zastrze-

${ }^{40}$ Uzasadnienie projektu ustawy o ochronie informacji niejawnych; S. Jaworski, Sporzadzanie apelacji przez obrońcę w sprawie karnej, w której akta i uzasadnienie wyroku sq objęte klauzula ściśle tajne, „Monitor Prawniczy” 17/2011, s. 956 i n.

${ }^{41}$ Por. A. Bogusz, Nowe spojrzenie na ochrone informacji niejawnych, „Zabezpieczenia” nr 3/2012, s. 50 i n.

${ }^{42}$ Por. M. Jaśkowska, Nadawanie klauzuli tajności a kontrola Naczelnego Sąu Administracyjnego, Przegląd Sądowy” nr 10/2001, s. 23.

${ }^{43}$ Zob. R. Szałowski, Ochrona informacji niejawnych a prawo dostępu do informacji publicznej, „Ius Novum” nr 1/2013, s. 121 i n.

44 Uzasadnienie wyroku Wojewódzkiego Sądu Administracyjnego w Warszawie z dnia 8 grudnia 2011 r., II SA/Wa 1844/11, LEX nr 1153551. 
żone". Nadawanie, znoszenie, zawyżanie lub zaniżanie klauzul tajności stało się bowiem czynnością mogącą istotnie wpływać na treść zakazu karnego.

\section{Literatura}

1. Bączek P., Zagrożenia informacyjne a bezpieczeństwo państwa polskiego, Toruń 2005.

2. Bogusz A., Nowe spojrzenie na ochrone informacji niejawnych, "Zabezpieczenia” nr 3/2012.

3. Brocławik K., Czajka M., Prawnokarne aspekty ochrony tajemnicy zawodowej radcy prawnego, cz. I: Zagadnienia materialnoprawne, „Radca Prawny” nr 3/2001.

4. Brocławik K., Prawnokarne aspekty ochrony tajemnicy osób świadczacych pomoc praw$n q$, ,Czasopismo Prawa Karnego i Nauk Penalnych” nr 1/2000.

5. Czarny-Drożdżejko E., Odpowiedzialność karna za ujawnienie $i$ wykorzystanie informacji niejawnych (po nowelizacji), „Państwo i Prawo” nr 1/2013.

6. Gadecki B., Kodeks karny. Część szczególna. Art. 252-316. Komentarz, Warszawa 2017.

7. Hałas R.G., Komentarz do art. 265 k.k. [w:] Kodeks karny. Komentarz, red. A. Grześkowiak, K. Wiak, Warszawa 2017.

8. Hoc S., Karnoprawna ochrona tajemnicy zawodowej, funkcyjnej $i$ stużbowej, „Gdańskie Studia Prawnicze" nr 1/2008.

9. Hoc S., Kilka uwag dotyczacych przestęstwa z art. 265 k.k., „Wojskowy Przegląd Prawniczy" nr 4/2003.

10. Hoc S., Komentarz do art. 266 k.k. [w:] Kodeks karny. Komentarz, red. R. Stefański, Warszawa 2017.

11. Jaśkowska M., Nadawanie klauzuli tajności a kontrola Naczelnego Sadu Administracyjnego, „Przegląd Sądowy” nr 10/2001.

12. Jaworski S., Sporzadzanie apelacji przez obrońcę w sprawie karnej, w której akta i uzasadnienie wyroku sa objęte klauzula ściśle tajne, „Monitor Prawniczy” 17/2011.

13. Kalitowski M., Komentarz do art. 265 k.k. [w:] Kodeks karny. Komentarz, red. M. Filar, Warszawa 2016.

14. Kozłowska-Kalisz P., Komentarz do art. 265 k.k. [w:] Kodeks karny. Komentarz, red. M. Mozgawa, Warszawa 2017.

15. Kunicka-Michalska B., Przestepstwa przeciwko ochronie informacji $i$ wymiarowi sprawiedliwości. Rozdziat XXX i XXXIII. Komentarz, Warszawa 2000.

16. Kunicka-Michalska B., Przestęstwa przeciwko ochronie informacji [w:] Przestęstwa przeciwko państwu i dobrom zborowym. System Prawa Karnego, t. 8, red. L. Gardocki, Warszawa 2013.

17. Leciak M., Prawnokarne aspekty nowej ustawy o ochronie informacji niejawnych, Studia Iuridica Toruniensia, t. IX, Toruń 2011.

18. Leciak M., Tajemnica państwowa i jej ochrona w prawie karnym materialnym i procesie karnym, Torun 2009.

19. Liderman K., Bezpieczeństwo informacyjne, Warszawa 2012.

20. Liedel K., Cyberbezpieczeństwo - wyzwanie przysztości. Dziatania społeczności międzynarodowej [w:] K. Liedel, P. Piasecka, T.R. Aleksandrowicz, Bezpieczeństwo w XXI wieku. Asymetryczny świat, Warszawa 2011. 
21. Nawrocki M., Kodeks karny. Komentarz [w:] Biegty w postepowaniu cywilnym i karnym. Komentarz praktyczny, orzecznictwo, wzory pism procesowych, red. K. Flaga-Gieruszyńska, Warszawa 2017, Legalis.

22. Piórkowska-Flieger J., Komentarz do art. 265 k.k. [w:] Kodeks karny. Komentarz, red. T. Bojarski, Warszawa 2016.

23. Sakowicz A., Komentarz do art. 265 k.k. [w:] Kodeks karny. Część szczególna, t. II: Komentarz do artykułów 222-316, red. M. Królikowski, R. Zawłocki, Warszawa 2017.

24. Szałowski R., Ochrona informacji niejawnych a prawo dostępu do informacji publicznej, „Ius Novum” nr 1/2013.

25. Szewczyk M., Prawnokarna ochrona tajemnicy zawodowej lekarza, „Czasopismo Prawa Karnego i Nauk Penalnych" nr 1/2000.

26. Wróbel W., Prawnokarna ochrona tajemnicy państwowej, „Czasopismo Prawa Karnego i Nauk Penalnych" nr 1/2000.

27. Wróbel W., Przestęsstwa przeciwko ochronie informacji [w:] A. Wąsek, Kodeks karny. Komentarz, t. II, Warszawa 2006.

28. Wróbel W., Przestępstwa przeciwko ochronie informacji [w:] A. Zoll, Kodeks karny. Komentarz, Warszawa 2008.

29. Zontek W., Sposoby wyznaczania zakresu treści normy sankcjonowanej. Uwagi na marginesie uchwaty SN z 26 marca 2009 r., sygn. akt I KZP 35/8, cz. 2, „Palestra” nr $1-2 / 2010$.

\section{Akty prawne}

1. Ustawa z dnia 6 czerwca 1997 r. Kodeks karny (tekst jedn. Dz.U. z 2017 r., poz. 2204 ze zm.).

2. Ustawa $\mathrm{z}$ dnia 5 sierpnia 2010 r. o ochronie informacji niejawnych (tekst jedn. Dz.U. z 2016 r., poz. 1167 ze zm.).

\section{Orzecznictwo}

1. Wyrok Wojewódzkiego Sądu Administracyjnego w Warszawie z dnia 8 grudnia 2011 r., II SA/Wa 1844/11, LEX nr 1153551.

2. Wyrok Naczelnego Sądu Administracyjnego w Warszawie z dnia 26 marca 2013 r., I OSK 2863/12, LEX nr 1332343.

3. Wyrok Sądu Apelacyjnego we Wrocławiu z dnia 16 czerwca 2016 r., sygn. akt II AKa 140/16, Lex nr 2073869.

4. Wyrok Sądu Najwyższego z dnia 8 marca 2007 r., sygn. akt I KZP 30/06, OSNKW nr 4/2007, poz. 32.

\section{SELECTED ASPECTS OF CRIME \\ DIRECTED AGAINST CLASSIFIED INFORMATION - ART. 265 AND 266 OF PENAL CODE}

The problems determining the proper protection of classified information and the consequences resulting from the disclosure of classified information, primarily containing data of special importance for the defense of the state have been presented in this paper. Infor- 
mation is currently in the catalog of the most important national properties, especially when it contains content that is very important for the defense of the state, its security and proper functioning. The article discusses, in particular, the offenses under art. 265 and 266 of penal code.

The offense of disclosure or use of classified information (regulated in art. 265 of penal code) provides for criminal liability of persons who disclose or contrary to statutory provisions, use classified information with a "secret" or "top secret" clause. This regulation describes unintentional disclosure of such information that has been read in connection with the acting of public function or authorization received and the qualified type covering the situation when the information was disclosed to a person acting on behalf of or in aid of a foreign entity.

However, on the basis of art. 266 of penal code criminal liability is imposed on persons who, contrary to the provisions of the Act or on their obligations, disclose or use information they have become acquainted with in their function, work, public, social, economic or scientific activities as well as public officers who disclose to unauthorized persons the secret information with the "reserved" or "confidential" clause or information obtained in connection with official activities, the disclosure of which may harm the legally protected interest.

Keywords: classified information, information protection, security, penal code.

DOI: 10.7862/rz.2018.mmr.6

Tekst złożono $w$ redakcji: luty $2018 r$.

Przyjęto do druku: marzec 2018 r. 
